\title{
Development of Multi-Purpose, Variable, Light Aircraft Simulator
}

\author{
Seunghee Yu, Yongjin Kwon* \\ Department of Industrial Engineering, College of Engineering, Ajou University, Suwon, South Korea \\ Email: *yk73@ajou.ac.kr
}

How to cite this paper: $\mathrm{Yu}, \mathrm{S}$. and Kwon, Y.J. (2017) Development of Multi-Purpose, Variable, Light Aircraft Simulator. Journal of Computer and Communications, 5, 4452.

https://doi.org/10.4236/jcc.2017.57005

Received: April 12, 2017

Accepted: May 14, 2017

Published: May 17, 2017

Copyright $\odot 2017$ by authors and Scientific Research Publishing Inc. This work is licensed under the Creative Commons Attribution International License (CC BY 4.0).

http://creativecommons.org/licenses/by/4.0/

(c) (i) Open Access

\begin{abstract}
Most aircraft simulators are manufactured separately for each model because the structure and flight characteristic of each model is different. However, light aircrafts are somewhat similar in terms of form and structure. In addition, from the flight schools' point of view, it is not economically beneficial to purchase and maintain light aircraft simulators for each different aircraft type. Globally, there are four types of light aircraft models that are most widely used for basic flight training. If all four models are separately selectable within a single flight simulator, there will be a lot of economic benefits in terms of reducing the purchasing costs as well as the reduction of pilot training costs. In this regard, this study aims at developing the multi-purpose variable-type simulator technology so that it can train four different aircraft types using only a single simulator. The utility of simulator is divided into the use of flight training and the use of leisure time. The flight characteristics are analyzed for each model type to emulate the actual aircraft. It is anticipated that the developed simulator can be produced at a lower cost while occupying less floor space and using less electric energy than the previous one.
\end{abstract}

\section{Keywords}

Simulator, Flight Training, Light Aircraft, Aeronautical, Cockpit Instrument

\section{Introduction}

Aircraft simulators are flight training equipment that provides an environment similar to an actual flight. It is customary to produce them by aircraft type for the purpose of performing type-specialized training [1]. In the case of a large aircraft cockpit, the shape and structure of each aircraft are different, but the shape and structure of small aircraft are similar. Globally, there are four types of light aircraft models that are most widely used for basic flight training. If all four models are separately selectable within a single flight simulator, there will be a 
lot of economic benefits in terms of reducing the purchasing costs as well as the reduction of pilot training costs. In addition, from the flight schools' point of view, it is not economically beneficial to purchase and maintain light aircraft simulators for each different aircraft type. Therefore, by developing the multipurpose variable-type simulator technology, it is possible to train four models in one light aircraft simulator [2]. The selected four types of light aircraft are the most widely used light aircraft for pilots training around the world, including Cessna 172, Carenado CT182T, Carenado SR-22 and DA-42. The flight characteristics are analyzed for each model type to emulate the actual aircraft. In fact, the flight simulator is an essential part of aviation training. Without the simulator, the pilots cannot be able to train under various conditions. In real-world using a real aircraft, it is simply impossible to expose the expensive vehicle and the life of the trainee pilots, in an attempt to acquire the skills under many adverse conditions. Therefore, most aviation training schools resort to the simulator and use it for adverse weather condition training or for emergency steps under system malfunctions [3]. In this way, the life of the pilots and the aircraft itself can be preserved without any danger. The importance of simulators is increasing, due to the fact that the newer aircraft becomes more and more expensive. In addition, the life of passengers and the value of onboard cargos are also considered irreplaceable [4]. Hence, the aircraft accidents need to be avoided at all costs. In this regard, the aviation training schools use the simulators more than ever, and the training costs and efficiency become crucial.

Therefore, the purpose of this study is to develop a touchscreen-based multipurpose variable light aircraft simulator that implements four types of aircraft models in one system. The goal is to develop a simulator that can be converted between four different models according to the user's request, so that it can train four kinds of models by using only one simulator. With such technology, it is possible to maximize the training effect, while reducing the procurement and training costs. However, if such simulator should be used for training, the simulator should be highly accurate in terms of reproducing the flight characteristics of each aircraft type. The exterior and the location of each control knob also need to be accurately reproduced [5]. Both physical layout and the operating software, therefore, should be close to the real system. According to our literature review, the development of such simulation system is hardly reported. If successful, our effort will bring about many advantages to both pilots and the training schools.

\section{Light Aircraft Analysis}

The heart of this development is flight characteristics data from which deriving simulated flight envelops and a display method for graphically displaying it to the user. The development process is as follows.

1) Analyze the instrument configuration and characteristics of each light aircraft to be implemented and select the instruments needed for actual flight training. Establish data linkage algorithm between simulation and instrument 
and verify whether simulation data and instrument data are the same and working in real time.

2) Establish data linkage algorithm between simulation and instrument, and design gauge panel for each model and instrument module. Verify that the function works properly. Implement touch display specification definition and touch input calculation algorithm for display in the size similar to actual instrument panel of aircraft.

3) Control plane and engine power control for each aircraft model. After defining the specification, make a design drawing and construct hardware similar to the cockpit of light aircraft.

Each light aircraft to be implemented is globally known and selected for use in many countries. They have stable flight performance, reasonable prices, and reasonable size as a light aircraft. Table 1 describes the four light aircraft selected in this study, including the aircraft's Producer, Image, Type, Engine, and Max Numbers of Passengers.

\section{Software Design}

The software design of the flight simulator for multipurpose variable light aircraft refers to the data linkage algorithm and the instrument panel design between the simulation and the instrument. It extracts simulated flight data inside the simulation and manages the data without missing any critical parameters. We extended the information extraction technology of the simulation flight through the microprocessor and applied it to the software design [6].

\section{Instrument Panel Design}

Instrument panel design requires the following.

- Precise instructions are required because the measurement range of temperature, pressure, and the speed range is very wide.

- Since the aircraft is fast, it is easy to judge the scale or indication of each instrument.

Table 1. Light aircraft information for simulator production.

\begin{tabular}{|c|c|c|c|c|}
\hline & Cessna172 & Carenado CT182 & Carenado SR-22 & DA-42 \\
\hline Producer & $\begin{array}{c}\text { Cessna Aircraft } \\
\text { Company }\end{array}$ & $\begin{array}{c}\text { Cessna Aircraft } \\
\text { Company }\end{array}$ & $\begin{array}{l}\text { Cirrus Design } \\
\text { Corporation }\end{array}$ & $\begin{array}{c}\text { Diamond Aircraft } \\
\text { Industries Inc. }\end{array}$ \\
\hline Image & & & & aLAB: DA4 \\
\hline Type & $\begin{array}{c}\text { Four-seater } \\
\text { lightweight aircraft }\end{array}$ & $\begin{array}{c}\text { Four-seater } \\
\text { lightweight aircraft }\end{array}$ & $\begin{array}{c}\text { Four-seater } \\
\text { lightweight aircraft }\end{array}$ & $\begin{array}{c}\text { Four-seater } \\
\text { light-weight aircraft }\end{array}$ \\
\hline Engine & Lycoming IO-360-L2A & $\begin{array}{c}\text { Lycoming } \\
\text { IO-540-AB1A5 }\end{array}$ & $\begin{array}{c}\text { Teledyne } \\
\text { Continental } \\
\text { IO-550-N }\end{array}$ & $\begin{array}{l}\text { Lycoming } \\
\text { IO-360-M1A }\end{array}$ \\
\hline $\begin{array}{l}\text { Max. No. of } \\
\text { passengers }\end{array}$ & $\begin{array}{c}\text { 4People (1 Pilot, } 3 \\
\text { Passengers) }\end{array}$ & $\begin{array}{c}4 \text { People (1 Pilot, } 3 \\
\text { Passengers) }\end{array}$ & $\begin{array}{c}4 \text { People (1 Pilot, } 3 \\
\text { Passengers) }\end{array}$ & $\begin{array}{c}4 \text { People (1 Pilot, } 3 \\
\text { Passengers) }\end{array}$ \\
\hline
\end{tabular}


- Adopt a compound gauge that allows a combination of multiple instruments or systems to be combined in one instrument in a readable manner, or a comprehensive indication of a lot of information needed for a particular purpose in one instrument.

- If you do not need to read the scale of the meter in detail, use visual marking or color marking [7].

Figures 1-3 show the four different types of touch screen-based instrument panels that are exactly the same as the actual aircraft, which have been designed by our team. The gauge panel below has the same image as the actual light aircraft. The instrument panel consists of various systems such as Airspeed Indicator, Horizontal Indicators, Altimeter, Turn Indicator, Heading Indicator, Vertical Speed, Fuel, Nav GPS Annunciator, Gear Switches, Magnetic Compass, Communications Switches, Flap Control Lever, and many more. The developed model uses G1000 system except C172, and C182, DA42, and SR22 are combined using PFD and MFD. The G1000 system is typically an integrated avionics system that provides information such as communication, navigation, flight

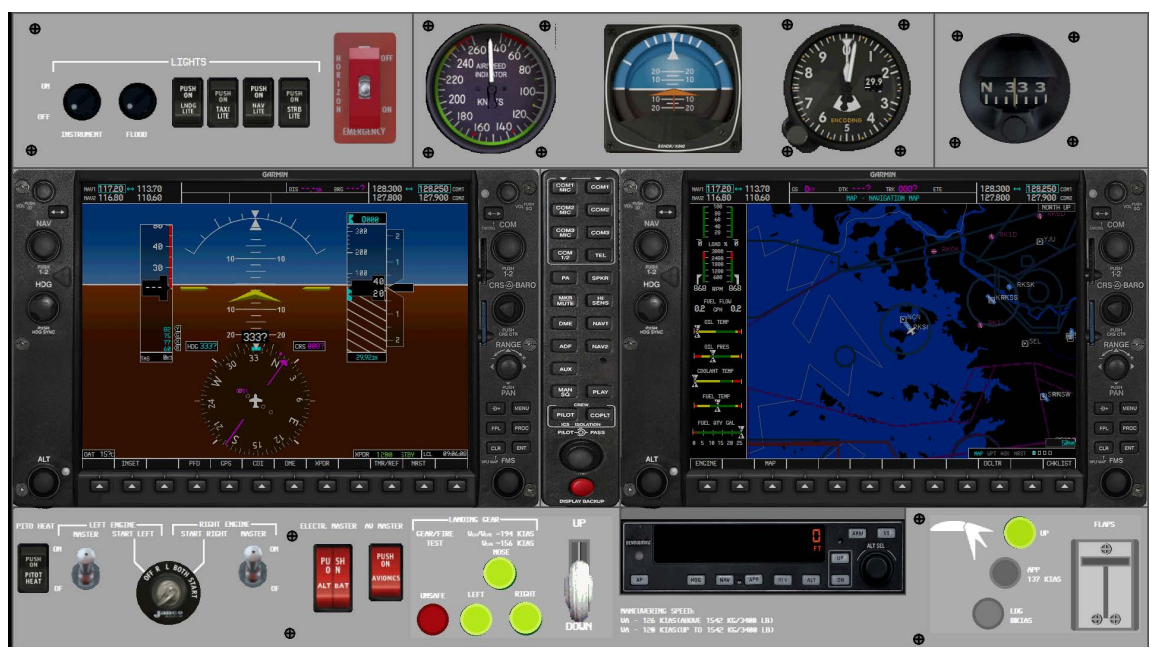

Figure 1. Instrument panel realization of C182 model.

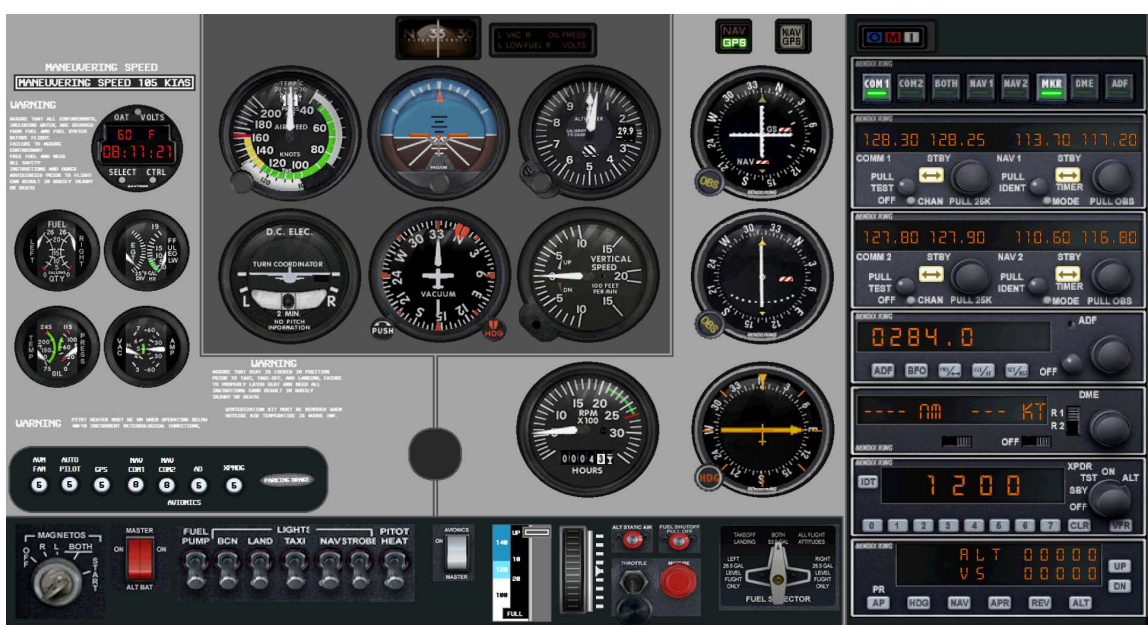

Figure 2. Instrument panel realization of C172 model. 


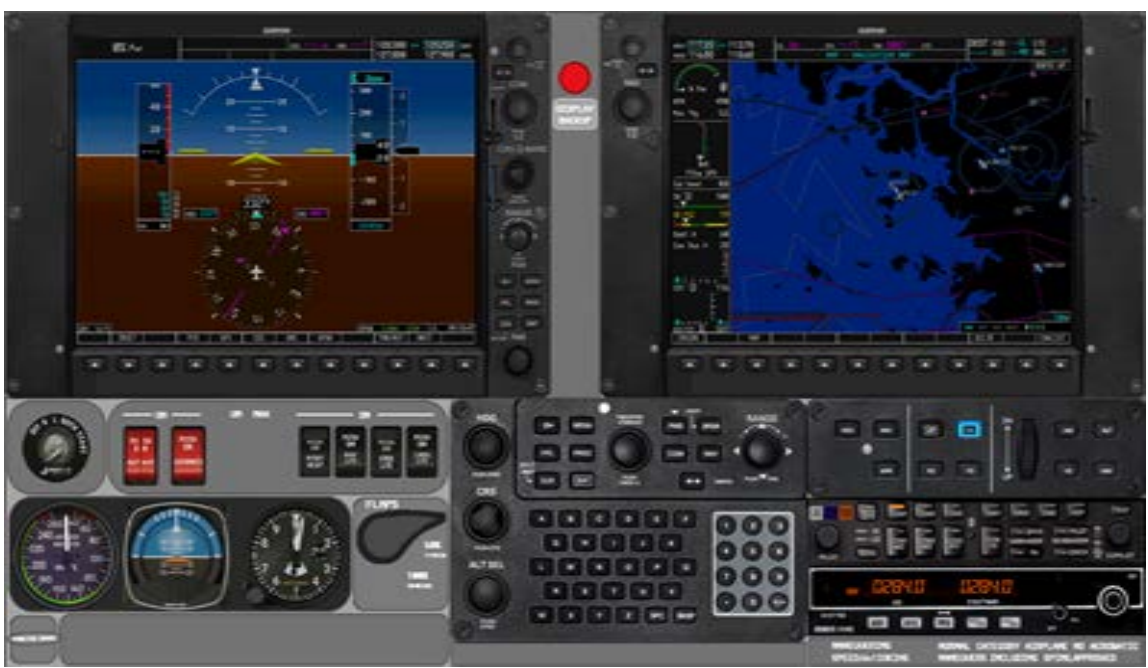

Figure 3. Instrument panel realization of SR22 models.

guidance, flight instrumentation, and aircraft system monitoring. The units provide the weather data, attitude data, heading data, communications, navigation, transponders, weather radar, satellite-broadcast weather information, traffic information, measurement data of the engine and fuel system. This is precisely demonstrated. In addition, the G1000 system analyzes the aircraft system status, displays the status of the aircraft in emergency and abnormal situations and advisory situations. It has the ability to automatically detect, report and adjust the various functions.

\section{Hardware Design}

\subsection{Design Drawing Production}

In order to construct a realistic cockpit, we measured the interior of the light aircraft and made a display stand using Sketch-Up CAD software, based on the actual information. Figure 4 illustrates the example design drawing.

Based on the drawings, the prototype was designed, the information was verified, and finally the drawing was revised. Figure 5 is a final prototype drawing, prior to the actual production.

\subsection{Panel Production}

The simulator is composed of functional modules and is made to be convenient for maintenance in the future. Each panel was painted first and then an engraving was made to reproduce the cockpit markings as the real aircraft. By inserting the backlight, it provides the environment similar to cockpit of actual aircraft, thereby enhancing visibility [8]. The assembling process using the completed drawing is as follows. After preparing the parts and the base panel, assemble the base frame first. Each separate frame is grouped into one form. Assemble the handles for control, and make throttle assembly, propeller pitch control knob, gasoline mixture levers, and so on. Finally, the cover is made. Before the fabrication of exterior components, our team developed the simulator software. The 


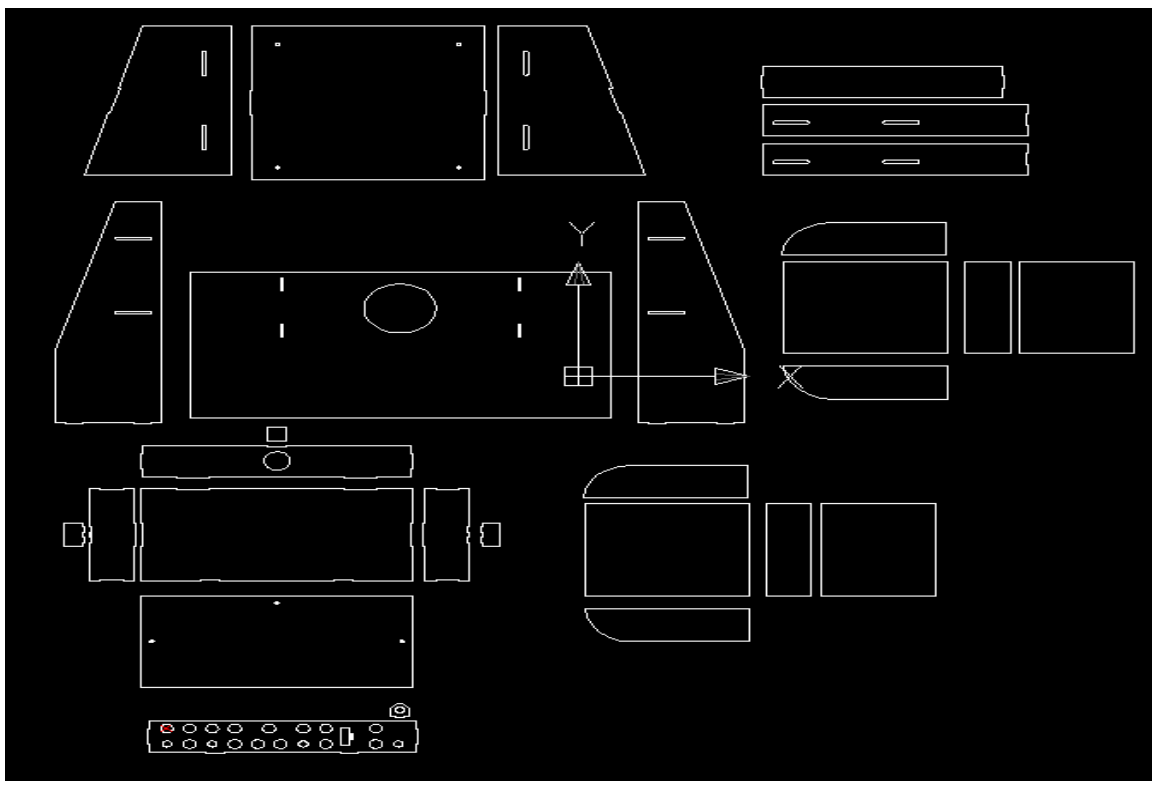

Figure 4. Drawing with Sketch-up CAD software.

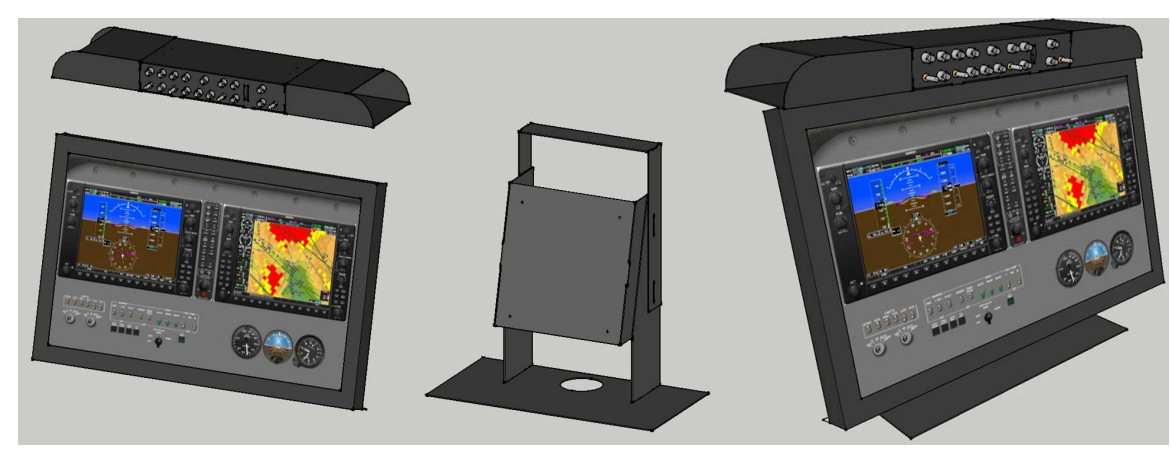

Figure 5. Design and integration of prototype.

workings of the SW has been extensively tested and verified according to the aviation regulations. Each gauge, instrument, and the switch have been faithfully reproduced. Under user input, each switch and dial can be rotated or pushed. Then, the associated instrument gauge graphically adjusts the status of each gauge. The instrument design (for pilot user interface) is integrated with aircraft flight data. The test platform is shown in Figure 6.

Figure 7 shows the exterior of the assembled simulator. After the completion, the final data interlock test and operation test were carried out, and all functions were confirmed to be working normally and properly [9]. Table 2 shows the evaluation results of the simulator developed in this study. All five items were evaluated, and almost all of them reached the target value, resulting in satisfactory results.

\section{Conclusion}

As a result of evaluating the five important evaluation factors (that is, 1) takeoff, 2) ascend, 3) flight, 4) braking, 5) engine), all grades were A-grade. The evaluation category and the methods were followed by the government issued standard 


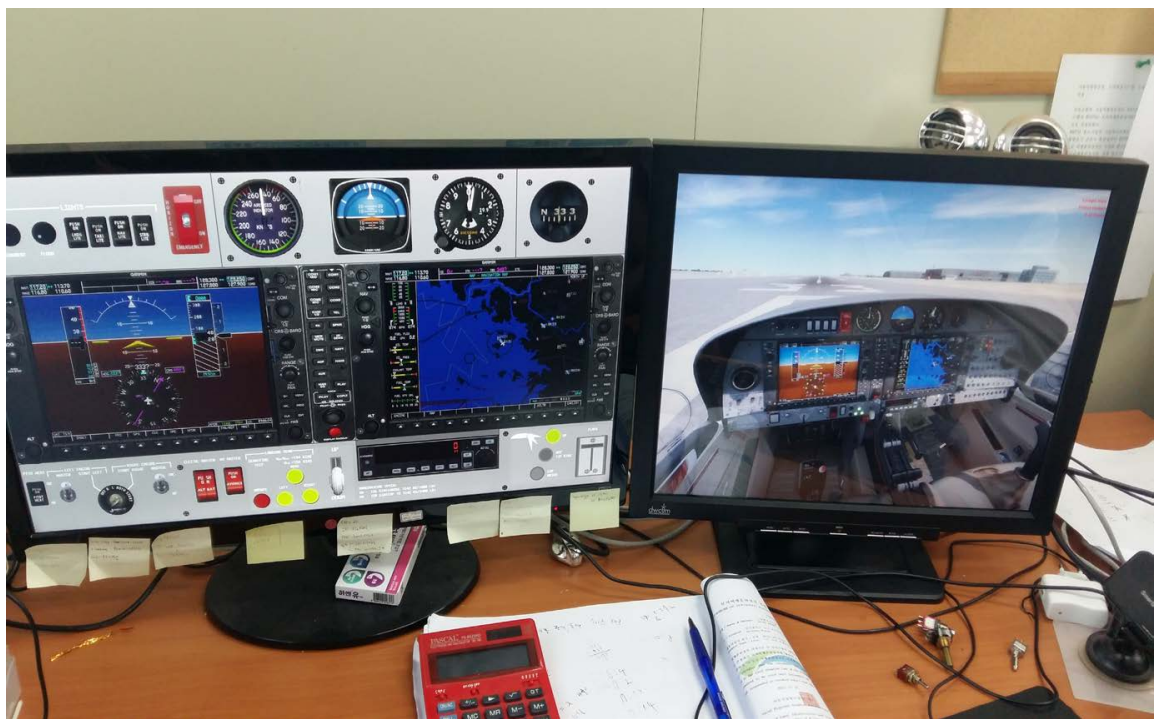

Figure 6. Verification of software design for each aircraft model.

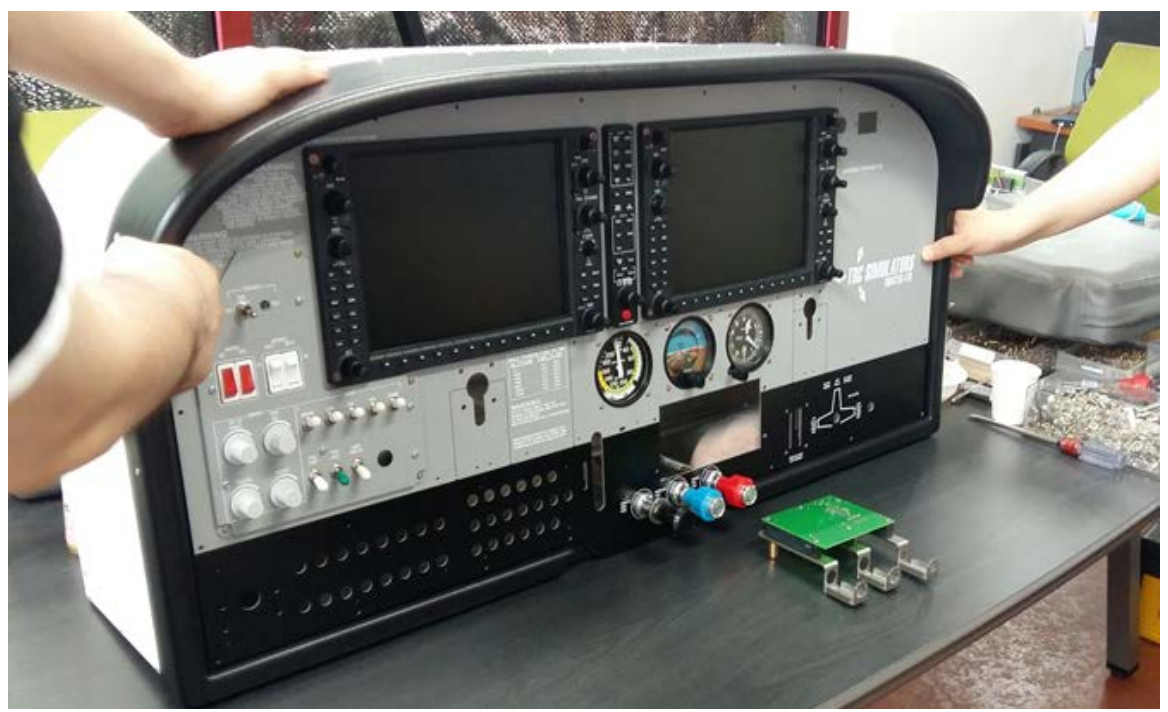

Figure 7. The exterior of completed simulator.

procedure. The end outcome shows that in all five categories, the developed simulator acquired A-grade. This indicates that the simulator is deemed suitable for training purposes in certified flight schools. Light aircraft training is the basis of all aviation training because it is used at the beginning of pilot training. Practical simulator training before actual flight is expected to be used in future. In addition, it seems to be possible to localize and develop the software design, hardware production, interworking, operation and testing necessary for running the simulator [10]. It will also block monopolies in the proprietary flight simulator equipment market and open new markets. It is expected to be used in various industries by lowering the unit price of related equipment by mixing the equipment used as the professional Flight Simulator as the experience equipment. As a result, if the simulator market is formed, it will have the effect of replacing imports and increasing exports. 
Table 2. The evaluation results of the developed simulator.

\begin{tabular}{|c|c|c|c|c|c|}
\hline \multicolumn{2}{|c|}{$\begin{array}{l}\text { Evaluation } \\
\text { Category }\end{array}$} & Unit & \multirow{2}{*}{$\begin{array}{c}\text { Target } \\
\text { Values }\end{array}$} & \multirow{2}{*}{$\begin{array}{c}\begin{array}{c}\text { Evaluation } \\
\text { Result }\end{array} \\
\text { VMO: } 181.6 \\
\text { MMo: } 0.00\end{array}$} & \multirow{2}{*}{$\begin{array}{c}\text { Grade } \\
\text { A }\end{array}$} \\
\hline \multirow{5}{*}{ 1. Takeoff } & Acc. Time & Time (Sec.) & & & \\
\hline & Takeoff Speed & $\begin{array}{c}\text { Knots, Pitch } \\
\text { (Degree) }\end{array}$ & $\begin{array}{l}\text { Vmax: } 140.5 \\
\text { See-level }\end{array}$ & $\begin{array}{c}\text { Vmax: } 139.2 \\
\text { See-level }\end{array}$ & A \\
\hline & Normal Takeoff & & $\begin{array}{l}\text { MCR: } 1150 \\
\text { OCP: } 83.1\end{array}$ & $\begin{array}{l}\text { MCR: } 1140 \\
\text { OCP: } 83.1\end{array}$ & A \\
\hline & $\begin{array}{l}\text { Engine Mal. } \\
\text { Function }\end{array}$ & $\begin{array}{l}\text { Knots, Pitch } \\
\text { (Degree), } \\
\text { Feet }\end{array}$ & $\begin{array}{l}\text { TRR: } 75 \\
\text { TRS: } 310 .\end{array}$ & $\begin{array}{l}\text { TRR: } 74 \\
\text { TRS: } 310 .\end{array}$ & A \\
\hline & $\begin{array}{l}\text { Lateral Wind } \\
\text { Condition }\end{array}$ & & $\begin{array}{c}\text { AA: } 17.0 \\
\text { AUA: } 15.0\end{array}$ & $\begin{array}{c}\text { AA: } 16.0 \\
\text { AUA: } 15.0\end{array}$ & A \\
\hline \multirow{3}{*}{ 2. Ascend } & $\begin{array}{c}\text { Normal } \\
\text { Ascending }\end{array}$ & $\begin{array}{l}\text { Knots, Pitch } \\
\text { (Degree), } \\
\text { Feet }\end{array}$ & $\begin{array}{l}\text { TCR: } 1170 \\
\text { TCS: } 60.9\end{array}$ & \multirow{3}{*}{$\begin{array}{l}\text { TCR: } 1160 \\
\text { TCS: } 60.0\end{array}$} & \multirow{3}{*}{ A } \\
\hline & $\begin{array}{l}\text { One engine Mal. } \\
\text { function }\end{array}$ & $\begin{array}{l}\text { Knots, FPM } \\
\text { (Feets Per }\end{array}$ & $\begin{array}{l}\text { FM: } 1 \text { - } 4 \\
\text { inop }\end{array}$ & & \\
\hline & One engine Icing & Minute) & $\begin{array}{c}\text { FMi: } 1 \text { - } 4 \\
\text { inop }\end{array}$ & & \\
\hline 3. Flight & $\begin{array}{l}\text { Stall Warning } \\
\text { Stall Warning } \\
\text { Device ON }\end{array}$ & $\begin{array}{l}\text { Knots, Pitch } \\
\text { (Degree) }\end{array}$ & $\begin{array}{l}\text { CS: } 126.8 \\
\text { NTS: } 74.5 \\
\text { VSO: } 47.4\end{array}$ & $\begin{array}{l}\text { CS: } 125.5 \\
\text { NTS: } 43.5\end{array}$ & A \\
\hline \multirow[b]{2}{*}{ 4. Braking } & $\begin{array}{c}\text { Braking } \\
\text { Time(Dry) } \\
\text { Thrust Reverse } \\
\text { Braking Time } \\
\text { (Dry) }\end{array}$ & \multirow[b]{2}{*}{ Time(Sec.) } & $\begin{array}{c}\text { iRPM: } 673 \\
\text { RRPM: } 2600\end{array}$ & $\begin{array}{c}\text { iRPM: } 672 \\
\text { RRPM: } 2595\end{array}$ & $\mathrm{~A}$ \\
\hline & $\begin{array}{l}\text { Braking Time } \\
\text { (Wet) }\end{array}$ & & $\begin{array}{c}\text { TFC: } 52.00(\mathrm{G}) \\
\text { TFW: } 316.0(\mathrm{P}) \\
\text { FFS: } 0850 \\
\text { CoGE: } 12.2 \\
\text { CoGNF:12.2 } \\
\text { CoGF: } 13.5\end{array}$ & $\begin{array}{c}\text { TFC: } 51.50(\mathrm{G}) \\
\text { TFW: } 316.0(\mathrm{P}) \\
\text { FFS: } 0840\end{array}$ & A \\
\hline 5. Engine & Acceleration & & $\begin{array}{c}\text { cl_max: } 1.400 \\
\text { CSS: } 53.9 \\
\text { TBS: } 0.650 \\
\text { DBS: } 0 \\
\text { HSC: } 0\end{array}$ & $\begin{array}{c}\text { cl_max: } 1.400 \\
\text { CSS: } 53.5\end{array}$ & A \\
\hline
\end{tabular}

\section{Acknowledgements}

This work was supported by the Ajou University research fund. 


\section{References}

[1] Park, J., Jang, D., Choi, H., Tak, M., No, J. and Kim, S. (2013) Integrated Simulator of Airborne Multi-Function Radar Resource Manager and Environment Model. KSAS Journal, 41, 577-587.

[2] Oh, H., Choi, K. and Lee, H. (2014) Implementation of Aircraft Control Simulator Server and Pilot Station Considering of Next Generation Navigation System. KSAS Conference, 1637-1640.

[3] Park, J. (2014) Study on Efficient Light Aircraft Design by Integrated Database Development. Konkuk University, Seoul.

[4] Cheon, Y.H., Lee, S.P. and Park, J.H. (2014) Aviation Communication Technique: Considering the Multi-Purpose Display Designed for Aircraft Lightning Protection. KONI, 445-454.

[5] Choi, H., Lee, S. and Jo, J. (2013) Conceptual Design of Multi-Purpose Modular Aircraft. KSAS Journal, 1071-1074.

[6] Google (2017) Flight-Simulator. http://www.dailian.co.kr/news/view/614459/?sc=naver

[7] No, G., Demyanov, M., Park, J., Lee, S., Kim, I. and Ko, S. (1999) A Study on Engineering Simulator Application for Aircraft Development. KSAS Journal, 105-109.

[8] Lee, D., Jang, I., Park, H., Kim, W., Kim, S., Park, D. and Yang, S. (2012) Weapon Simulator Used for Armed Helicopter. KSAS Conference, 865-868.

[9] Naver Flight Simulator (2017). http://www.kukinews.com/news/article.html?no=441200

[10] Choi, S., Chae, S., Han, Y. and Lee, C. (2003) 3D Flight Simulator for Education of Flying Tactics. KSS Journal, 1-11.

Submit or recommend next manuscript to SCIRP and we will provide best service for you:

Accepting pre-submission inquiries through Email, Facebook, LinkedIn, Twitter, etc. A wide selection of journals (inclusive of 9 subjects, more than 200 journals)

Providing 24-hour high-quality service

User-friendly online submission system

Fair and swift peer-review system

Efficient typesetting and proofreading procedure

Display of the result of downloads and visits, as well as the number of cited articles

Maximum dissemination of your research work

Submit your manuscript at: http://papersubmission.scirp.org/

Or contact jcc@scirp.org 